\title{
Organ Distribution of the Three Rat Endothelin Messenger RNAs and the Effects of Ischemia on Renal Gene Expression
}

\author{
J. D. Firth and P. J. Ratcliffe \\ Institute of Molecular Medicine, John Radcliffe Hospital, Headington, Oxford OX3 9DU, England
}

\begin{abstract}
To determine the organ distribution of production of the three endothelin (ET) isopeptides, we have developed three ribonuclease protection assays specific for the messenger RNAs ( mRNAs) of rat ETs 1, 2, and 3.12 organs from adult SpragueDawley rats were examined: heart, lung, liver, spleen, kidney, stomach, small intestine, large intestine, testis, muscle, salivary gland, and brain. The mRNA for ET1 was five times more abundant in the lung than in any other organ studied, moderate expression was seen in the large intestine, and lower levels of mRNA were detected in each of the other organs examined. ET2 was expressed at high level in both large and small intestine and at low level in stomach, muscle, and heart, but ET2 mRNA could not be detected elsewhere. ET3 mRNA was found in all organs, particularly in small intestine, lung, kidney, and large intestine.

Because of reports suggesting that ETs might be involved in the hypoperfusion and hypofiltration observed in postischemic kidneys, we have also studied levels of mRNA in kidneys that had previously been subjected to 25 or $45 \mathrm{~min}$ of clamping of the renal pedicle. At $6 \mathrm{~h}$ after $45 \mathrm{~min}$ of ischemia, ET1 mRNA increased to a peak of $421 \pm 69 \%(\operatorname{mean} \pm \operatorname{SEM}, n=3)$ of that in a standard renal RNA preparation. By contrast, ET3 mRNA decreased in the postischemic organ, falling to a value of $19 \pm 2 \%$ of standard at the same time point. The effects of ischemia on ET1 and ET3 mRNAs were long-lasting, with elevation of ET1 and depression of ET3 persisting for days. ET2 mRNA remained undetectable throughout. These findings $(a)$ support a role for ET1 in postischemic renal vascular phenomena and $(b)$ demonstrate a situation in which the expression of ET isoforms is clearly subject to differential regulation. ( $J$. Clin. Invest. 1992. 90:1023-1031.) Key words: acute renal failure • gene expression • RNAase protection assay
\end{abstract}

\section{Introduction}

The endothelins (ETs) ${ }^{1}$ are a family of three 21 -amino acid peptides that are both potent vasoconstrictors and have mitogenic properties (1-3). The power of these effects suggests im-

Address reprint requests to Dr. Firth, Institute of Molecular Medicine, John Radcliffe Hospital, Headington, Oxford OX3 9DU, United Kingdom. 1992

Received for publication 6 January 1992 and in revised form 9 April

1. Abbreviation used in this paper: ET, endothelin.

J. Clin. Invest.

(c) The American Society for Clinical Investigation, Inc.

0021-9738/92/09/1023/09 \$2.00

Volume 90, September 1992, 1023-1031 portant physiological or pathophysiological action, but their functions remain elusive. The concentrations of mature peptides within the circulation are usually lower than those reported to have biological activity (4). This, coupled with the demonstration of similar localizations of ET mRNA and ET binding sites in various organs (5), has led to the suggestion that the ET system functions largely in an autocrine or paracrine manner (5). Estimates of tissue concentrations of ET have been reported (6-8). However, such studies suffer from the problem that currently available radioimmunoassays are not capable of distinguishing between ETs 1 and 2, which differ by only two or three amino acids (depending on species).

Production of ETs appears to be regulated predominantly through modulation of mRNA levels (1). Thus it is likely that measurement of such levels would reflect endothelin activity. RNAase protection techniques have therefore been developed which are capable of discerning between the mRNAs of each of the three rat ETs. This method is considerably more sensitive than Northern blotting and, because more than a single basepair mismatch between probe and template leads to failure of hybridization (9), has the specificity to distinguish between ETs 1, 2, and 3. The tissue distributions of the three endothelin $\mathrm{mRNAs}$ are reported, as are the effects of unilateral renal ischemia on renal levels of $\mathrm{mRNAs}$ encoding for the three isopeptides.

\section{Methods}

Cloning of fragments of the three rat ET genes. A combination of PCR and library screening techniques were used to clone genomic fragments of the genes for rat ETs 1, 2, and 3. Further subcloning procedures served to generate smaller fragments optimal for the production of labeled antisense RNA transcripts appropriate for use in RNAase protection assays. In each case these included the coding sequence for a substantial fragment of the mature ET peptide, with adjacent 5 ' intron.

ET1. A two-stage polymerase chain reaction (PCR) technique was used: this involved partially nested primers designed from human sequence information (10) and $1 \mu \mathrm{g}$ of rat genomic DNA as initial template. The first stage (primers: sense GGCTTGCCAAGGAGCTCC, oligo 1; antisense ACTCGGGAGTGTTGACCC, oligo 2) was conducted in buffer containing 7-deaza-2-deoxy GTP $150 \mu \mathrm{mol} /$ liter and dGTP $50 \mu \mathrm{mol} /$ liter, all other nucleotides being present at a concentration of $200 \mu \mathrm{mol} /$ liter. After initial denaturation at $94^{\circ} \mathrm{C}$ for $4 \mathrm{~min}, 33$ cycles were performed according to the schedule: $94^{\circ} \mathrm{C} 1 \mathrm{~min}, 60^{\circ} \mathrm{C} 1$ $\min , 72^{\circ} \mathrm{C} 2 \mathrm{~min} .10 \mu$ of product served as the template for the second stage PCR reaction (primers: sense, oligo 1; antisense CAAATGATGTCCAGGTGGCA, oligo 3) conducted in standard buffer (all nucleotides $200 \mu \mathrm{mol} /$ liter) using the same temperature cycling parameters as for the first stage of the amplification. This yielded a $1.8-\mathrm{kb}$ product spanning the region between exons 1 and 2 . By means of standard techniques a 600 -bp fragment produced by digestion of this product with Asp 718 was subcloned into the Asp718/Hind II sites of the riboprobe vector pAM19 (Amersham International, Amersham, UK), and an intronic Bgl II site $242 \mathrm{bp}$ from the $3^{\prime}$ end of the insert was used to linearize the template. The partial DNA sequence given for rat ET1 (Fig. 1), determined by the dideoxy chain termination method (Se- 
ET1 TTC CTA CTA AOC CGA $\cong$ TCT GTT CTC TIC ACA CCT GTC TTG

ET2 AGG TGT .CT GA .TC .T. ..C ACC TCT C.. T.C CTC C.G.GT

ET3 GAG ACC A.T GIG ICC A A.A C. GCA C.G C.T, A CAG $\infty$

ET1 GGA GAA GAG CTC ACC OC CGA GCT GAG AAG GAA GIG CAG ACC

ET2 CC. .GG A.. GG OAG G.A GCT ... AOC .TG ..G CAA .CA GG

ET3 ... AAT .CT GBG OAG GAG ..G .GA OA GCC AGG TCT GG GA

ET1 $O C \cong T$ OC ACC ACA TOC TEG GGA $\cong C$ CEC AGG TOC AAG OGT

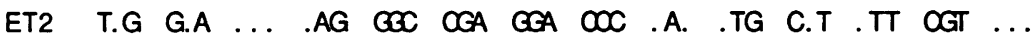

ET3 .AG GA GAA .AG .GG GIG $\propto$ CT .C. .A. .A. C.A $\quad$ C.T $O G$..C

ET1 TGC TCC TGC TCC TCC TTG ATG GAC AAG GAG TGT GTC TAC TTC

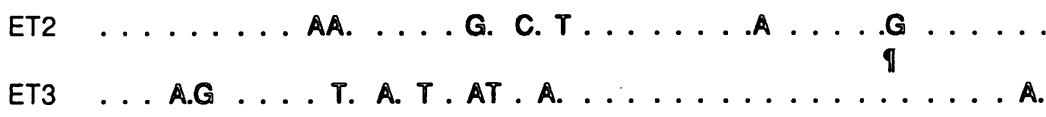

ET1 TGC CAC CTG GAC ATC ATC TGG

ET2 ................ GIG AAC ACT GCA G

ET3

$\ldots \ldots \ldots \ldots \ldots$
Figure 1. Partial nucleotide sequences of the three rat ET genes. Shown in outline script are the sequences coding for the mature peptides ETs 1, 2, and 3 .

*Those nucleotides in the mature peptide coding sequence of rat ET1 that differ from human ET1: these differences do not affect the predicted amino acid sequence. The presence of a dot indicates that the nucleotide present in ET2 or ET3 is the same as that found in ET1. 'The 3' end of the riboprobe constructs. Consensus splice site sequences are underlined: these represent the probable 5 ' ends of the protected fragments in the RNAase protection assays. quenase, United States Biochemical Corp., Cleveland, $\mathrm{OH}$ ), was obtained from this fragment and was extended to include the entire coding region for the mature peptide by sequencing DNA subsequently isolated from $\sim 10^{6}$ plaques of a rat genomic library ( $\lambda$ DASH, Stratagene, La Jolla, CA) by screening with the 600-bp Asp718 fragment labeled with ${ }^{32} \mathrm{P}$ by the random hexamer priming method according to the manufacturer's instructions (Amersham International). The sequences were identical, excepting a single base change in the oligo 3 region, which does not alter the predicted amino acid sequence, and confirmed the identity of rat ET1.

ET2. By using cDNA sequence information published for the rat ET2 gene (11) a 140-bp product was produced from $1 \mu \mathrm{g}$ of rat genomic DNA by PCR (primers: sense AAGGGCCAGGCAGCTGCT, oligo 4; antisense, oligo 3 ) in standard buffer using 35 cycles of the schedule: $94^{\circ} \mathrm{C} 1 \mathrm{~min}, 64^{\circ} \mathrm{C} 1 \mathrm{~min}, 72^{\circ} \mathrm{C} 10 \mathrm{~s}$. This product was used to screen the rat genomic library. Two positive $10.5-\mathrm{kb}$ clones were identified. The insert from one of these was excised using Sal I and subcloned into Bluescript (Stratagene). Further subcloning procedures were used to isolate a 221-bp Apa I/Pst I fragment in vector pSP72 (Promega Corp., Madison, WI). Sequencing confirmed this fragment to be rat ET2 (Fig. 1). A unique Bg1 II site within the polylinker adjacent to the $5^{\prime}$ end of the insert was used to linearize the riboprobe.

ET3. A two-stage PCR technique, similar to that used to clone the rat ET1 gene fragment, served to generate a short fragment of the human ET3 gene, which was then used to screen the rat genomic library. The upstream primer (sense AGCCCTGGAAGCCCTGG, oligo 5) was designed from sequence in exon 2 that was wholly conserved between humans and rabbits $(12,13)$. The first-stage reaction (primers: sense, oligo 5; antisense, oligo 2) was conducted in 7-deaza-2-deoxy GTP containing buffer and used $1 \mu \mathrm{g}$ of human genomic DNA as template. After initial denaturation at $94^{\circ} \mathrm{C}$ for $4 \mathrm{~min}, 33$ cycles were performed according to the schedule: $94^{\circ} \mathrm{C} 1 \mathrm{~min}, 64^{\circ} \mathrm{C} 1 \mathrm{~min}, 72^{\circ} \mathrm{C}$ $10 \mathrm{~s} .10 \mu \mathrm{l}$ of product was used as template for the second stage (primers: sense, oligo 5; antisense, oligo 3 ) conducted in standard buffer with the same cycling protocol. The expected 112-bp product was obtained (it was not when rat genomic DNA was used as template for the first-stage reaction and subsequent analysis showed that the oligo 5 sequence is not conserved in the rat). Screening of the library using this product revealed three positive clones. A 10-kb Sal I/Bgl II fragment of one of these was subcloned into pSP72 (Promega Corp.). Sequencing confirmed this to be rat ET3 (Fig. 1), which was reduced by further subcloning procedures to an 800 -bp Pst I/ Acc I fragment. A unique Bam $\mathrm{H} 1$ site within the polylinker adjacent to the $5^{\prime}$ end of the intron was used to linearize the riboprobe.

Study of organ distribution. Experiments were performed on male Sprague-Dawley rats weighing 250-320 $\mathrm{g}(n=4)$. Immediately upon induction of anesthesia (pentobarbital $60 \mathrm{mg} / \mathrm{kg}$ ) the following organs were swiftly removed: heart, lung, liver ( $\sim 1 \mathrm{~g}$ of right lateral lobe), spleen, kidney, stomach, small intestine ( $\sim 5 \mathrm{~cm}$ of jejenum), large intestine (from cecum to transverse colon), testis, muscle ( $\sim \mathrm{g}$ of thigh muscle), salivary gland, and brain (supratentorial and infratentorial). To avoid the possibility of contamination of tissues containing low levels of endothelin mRNAs with material from tissues containing high levels, the surgical instruments were washed after removal of each organ. The excised organs were weighed and each then immediately was homogenized by homogenizer (Polytron, Brinkmann Instru- 
ments, Inc., Westbury, NY) operated at full power for $90 \mathrm{~s}$ in $20 \mathrm{ml}$ of guandinium thiocyanate to which had been added 10-50 $\mu \mathrm{g}$ (depending on anticipated abundance of RNA in the organ homogenate) of RNA derived from K562 cells (a human erythroleukemia cell line producing abundant $\alpha$-globin mRNA) to provide an estimate of efficiency of mRNA recovery.

After homogenization, $0.5 \mathrm{~g} \mathrm{~N}$-lauroylsarcosine and $3 \mathrm{ml}$ of cesium chloride $(0.96 \mathrm{~g} / \mathrm{ml})$ were added to each $6.5-\mathrm{ml}$ aliquot of homogenate, the sarcosine was dissolved by vigorous vortexing, and the solution was layered on top of a 4-ml cesium chloride cushion. The samples were centrifuged at $32,000 \mathrm{rpm}$ at $20^{\circ} \mathrm{C}$ for $22 \mathrm{~h}$ in an ultracentrifuge (Beckman Instruments Inc, Palo Alto, CA). After centrifugation, the supernatant was removed, the RNA pellet was dissolved in $350 \mu$ l of 10 $\mathrm{mM}$ Tris, $\mathrm{pH} 7.5,1 \mathrm{mM}$ EDTA buffer with $0.2 \%$ SDS, and the RNA was precipitated with the addition of $35 \mu \mathrm{l}$ of $3 \mathrm{M}$ sodium acetate, $\mathrm{pH}$ 5.5 , and $2.5 \mathrm{vol}$ of absolute alcohol. RNA samples were stored at $-70^{\circ} \mathrm{C}$ before analysis.

Study of effects of renal ischemia. Experiments were performed on male Sprague-Dawley rats weighing 250-320 g. Under anesthesia (pentobarbital $60 \mathrm{mg} / \mathrm{kg}$ ) the left kidney was exposed through a flank incision and the renal pedicle totally occluded for 25 or $45 \mathrm{~min}$ by the application of an atraumatic vascular clamp. The clamp was then removed and surgical repair effected. Both right and left kidneys were removed 2, 6, and $24 \mathrm{~h}$ and 2 and $7 \mathrm{~d}$ later and RNA was extracted as described above ( $n=3$ each group).

RNAase protection assay. Continuously labeled antisense RNA transcripts to ETs 1,2 , and 3 were generated by in vitro transcription using SP6 polymerase (Amersham International) and $\left[\alpha{ }^{32} \mathrm{P}\right] \mathrm{GTP}$ $(410 \mathrm{Ci} / \mathrm{mmol}$, Amersham International). The same technique was also used to produce a probe that protected a 97-bp fragment of human $\alpha$-globin mRNA using a template construct extending from position -102 in the $\alpha$ promoter to the BssH I site in exon 1 of the human $\alpha$-globin gene. Preliminary experiments revealed that the rat ET probes did not protect any fragment of K562 RNA and the $\alpha$ globin probe did not cross-react with rat RNA. To ensure equivalent specific activity all hybridizations of samples run on a single gel were performed by using probes made from the same batch of $\left[\alpha-{ }^{32} \mathrm{P}\right] \mathrm{GTP}$.

For analysis of mRNA, the precipitated total RNA was dissolved in an aliquot of hybridization buffer ( $80 \%$ formamide, $40 \mathrm{mM}$ Pipes, 400 $\mathrm{mM}$ sodium chloride, $1 \mathrm{mM}$ EDTA, $\mathrm{pH} 8$ ) and the RNA concentration determined by absorbance measurements at $260 \mathrm{~nm}$ using a DU62 spectrophotometer (Beckman Instruments, Inc.). The concentrations were adjusted to yield $50-\mu \mathrm{l}$ samples containing $100 \mu \mathrm{g}$ of RNA, except in the case of assay of ET 1 abundance in lung, where the quantity of RNA was reduced to $25 \mu \mathrm{g}$. Hybridization was performed overnight at $60^{\circ} \mathrm{C}$ with $5 \times 10^{5} \mathrm{cpm}$ of the appropriate ET probe and 5 $\times 10^{5} \mathrm{cpm}$ of $\alpha$-globin probe. RNAase digestion was then carried out at $37^{\circ} \mathrm{C}$ for $30 \mathrm{~min}$, and terminated by the addition of $60 \mu \mathrm{l}$ of proteinase $\mathrm{K}(1 \mathrm{mg} / \mathrm{ml})$ with $3 \% \mathrm{SDS}$ and further incubation at $37^{\circ} \mathrm{C}$ for $30 \mathrm{~min}$. Phenol-chloroform and then chloroform extractions were performed and the RNA fragments precipitated with $2.5 \mathrm{vol}$ of absolute alcohol. The precipitated RNA was subsequently dissolved in $5 \mu \mathrm{l}$ of $80 \%$ formamide running buffer, and the reaction mix electrophoresed on a denaturing $10 \%$ polyacrylamide gel.

After electrophoresis the gels were dried and subjected to autoradiography at $-70^{\circ} \mathrm{C}$, after which the autoradiographs were aligned with their corresponding gels and the protected ET and $\alpha$-globin mRNA bands excised. These were then counted using a flat-bed liquid scintillation counter (model 1205 Beta Plate, Pharmacia-Wallac OY, Turkey, Finland) with a method which has been demonstrated to produce a linear response across the range of activities assayed in these experiments (14).

In the study of organ distribution the abundance of ET mRNA in each organ was described as a percentage of the quantity determined in a standard RNA preparation run simultaneously on the same gel. For ET1 and ET3 the standard preparation consisted of a mixture of RNA from pooled rat lungs (containing large amounts of ET1 and ET3 mRNA) and K562 RNA (containing a large amount of $\alpha$-globin
mRNA). For ET1 four quantities of standard were loaded onto each gel: ( $a$ ) no RNA; (b) $5 \mu \mathrm{g}$ of lung, $0.5 \mu \mathrm{g}$ of K562 RNA; $(c) 10 \mu \mathrm{g}$ of lung, $1 \mu \mathrm{g}$ of K562 RNA; (d) $20 \mu \mathrm{g}$ of lung, $2 \mu \mathrm{g}$ of K562 RNA. For ET3 the standards were: ( $a$ ) no RNA; $(b) 25 \mu \mathrm{g}$ of lung, $0.5 \mu \mathrm{g}$ of K562 RNA; (c) $50 \mu \mathrm{g}$ of lung, $1 \mu \mathrm{g}$ of K562 RNA; (d) $100 \mu \mathrm{g}$ of lung, $2 \mu \mathrm{g}$ of K562 RNA. For ET2 the standard was a mixture of RNA from pooled rat large intestine (containing a large amount of ET2 mRNA) and K562 RNA. The standards loaded comprised: ( $a$ ) no RNA; $(b) 25 \mu \mathrm{g}$ of large intestine, $0.5 \mu \mathrm{g}$ of K562 RNA; (c) $50 \mu \mathrm{g}$ of large intestine, $1 \mu \mathrm{g}$ of K562 RNA; (d) $100 \mu \mathrm{g}$ large intestine, $2 \mu \mathrm{g} \mathrm{K562} \mathrm{RNA.} \mathrm{Linear}$ regression analyses were used to describe the relationships between counts per minute of protected $\alpha$-globin and ET bands and the amounts of each standard loaded. The regression formulas obtained were then used to derive estimates of the quantity of $\alpha$-globin and ET mRNA present in each experimental sample. The efficiency of recovery of mRNA in each sample was estimated from the percent recovery of $\alpha$-globin. The quantity of ET mRNA was expressed as a percentage of that found in the standard RNA preparations.

In the study of renal ischemia the abundance of ET mRNA was expressed in relation to that present in a preparation of RNA from pooled rat kidneys. The standard RNA preparations comprised: $(a)$ no RNA; $(b) 50 \mu \mathrm{g}$ of renal, $0.5 \mu \mathrm{g}$ of K562 RNA; (c) $100 \mu \mathrm{g}$ of renal, $1 \mu \mathrm{g}$ of K562 RNA; (d) $200 \mu \mathrm{g}$ of renal, $2 \mu \mathrm{g}$ of K562 RNA. The analysis took the same form as that described for the study of organ distribution. Statistical comparison between each group of experimental kidneys and standard was made using an unpaired $t$ test. A two-sided $P$ value of $<0.05$ was taken as indicating significance.

\section{Results}

Partial nucleotide sequences of the genomic rat ET probes are shown in Fig. 1. The 63 nucleotide segment encoding the 21 amino acids of the mature rat ET1 peptide differs at five positions from its human counterpart, but these differences do not affect the predicted amino acid sequence. The location of a consensus splice site sequence (15) $154 \mathrm{bp}$ from the $3^{\prime}$ end of the riboprobe predicts a protected fragment of the size observed. The position of this consensus sequence is also the point at which homology with human ET1 genomic sequence (10) is lost. The rat ET2 probe contains $155 \mathrm{bp}$ of exonic sequence identical to that reported by Bloch et al. (11). In this region there is considerable homology with human ET 2 cDNA sequence (11). Adjacent is a consensus splice site sequence, $5^{\prime}$ to which homology with the human cDNA is lost. A protected ET2 fragment of $155 \mathrm{bp}$ was observed. The rat ET3 probe contains sequence identical to that reported by Yanagisawa et al. (16) and reveals a potential splice site $140 \mathrm{bp}$ from the $3^{\prime}$ Acc I site. A protected fragment of this length was obtained.

To test the specificity of the ET probes (ET1 vs. ET2 vs. ET3), the three riboprobe vectors were each linearized by cleavage at a unique polylinker site at the $3^{\prime}$ end of the ET insert. Sense RNA transcripts of genomic DNA encoding for each ET isoform were then generated by in vitro transcription using $\mathrm{T} 7$ RNA polymerase (Boehringer Mannheim $\mathrm{GmbH}$, Mannheim, FRG). The reaction, performed under conditions recommended by the manufacturer, was allowed to proceed for 30 min, after which DNA template was removed by digestion with DNAase I. RNA was recovered by precipitation with sodium acetate/alcohol and dissolved in hybridization buffer. $1 / 10,000$ th of the total yield of each product was then hybridized and processed (in separate reactions) with each ET probe, as described in Methods. Fig. 2 shows that there was no discernable cross-reaction between the three ET probes and the three ET sense RNA transcripts. The ET1 sense RNA transcript con- 


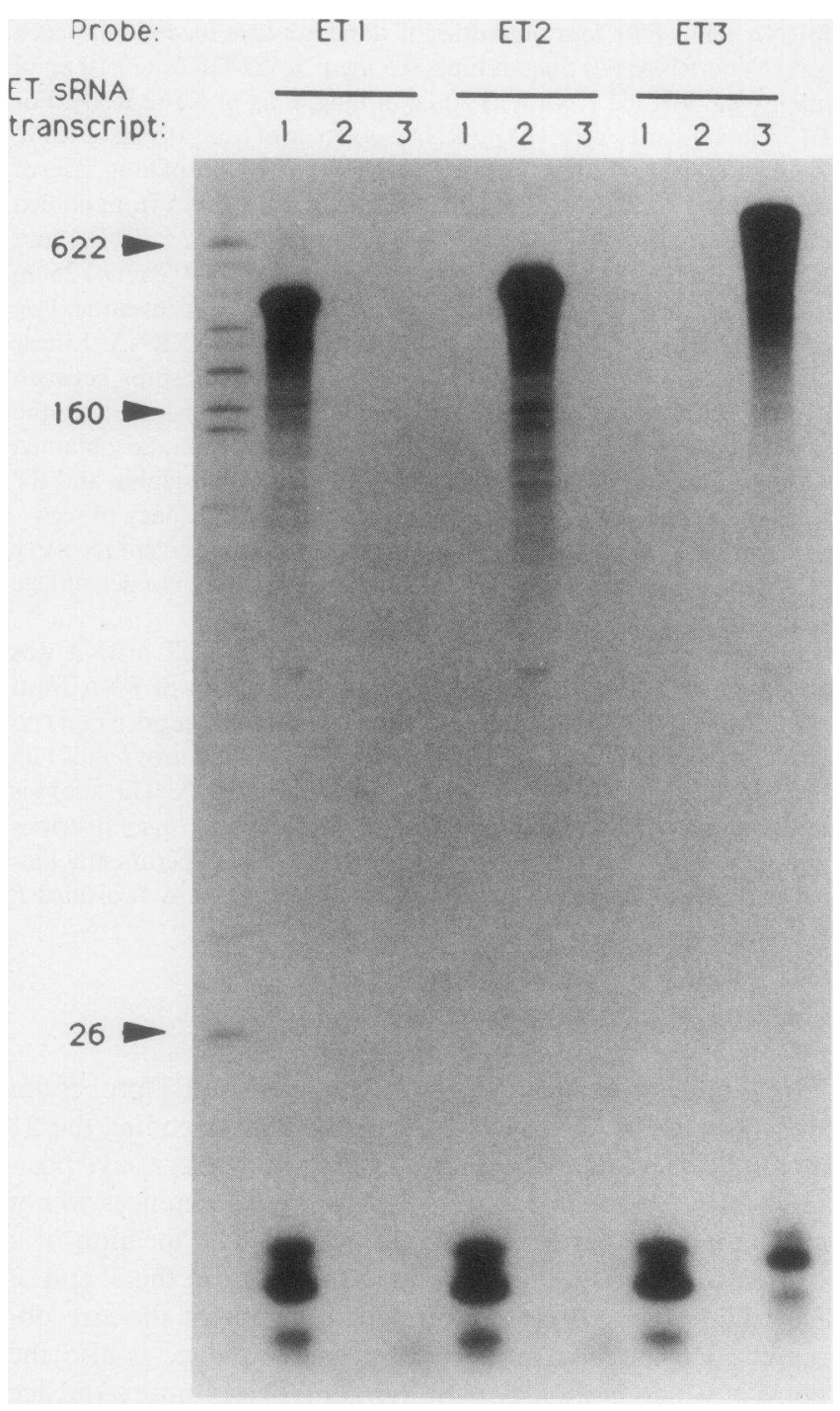

Figure 2. Autoradiograph, after $12 \mathrm{~h}$ of exposure, of an RNAase protection assay to demonstrate the specificity of the ET probes. Sense RNA transcripts of genomic DNA encoding each isoform of ET were hybridized with each probe (see Results). Full-length protection was conferred after hybridization of probe with homologous sense RNA. No protection was conferred, other than of very short fragments, by heterologous RNA. Markers: Hpa II digest of pBR322-26, 160, and 622 base-pair fragments are indicated.

ferred full-length protection on the ET1 probe (as expected), but no protected bands (other than at $<26$ bp in length) could be seen using the ET 2 or ET3 probes. In a similar manner, the ET2 sense RNA transcript protected the ET2 probe, but failed to protect either the ET1 or ET3 probes, and the ET3 sense RNA transcript protected the ET3 probe, but neither the ET1 nor ET2 probes. These findings strongly support the contention that the ET probes are highly specific for their own isoform of ET.

Organ distribution of the three ET mRNAs. Fig. 3 shows the organ distribution of mRNA for ET1. Protected bands of the expected length ( $154 \mathrm{bp}$ ) can be seen. These are most intense in samples from lung and large intestine. Also seen are two other protected fragments. The smaller, running at $97 \mathrm{bp}$, represents hybridization of $\alpha$-globin probe with $\alpha$-globin mRNA. The larger, running at $242 \mathrm{bp}$, is due to full-length hybridization with probe ET1 sequence. The probe itself is $272 \mathrm{bp}$, the additional $30 \mathrm{bp}$ owing to the inclusion of polylinker. The band representing full-length protection could be due to hybridization of probe either with contaminating rat DNA or with unspliced RNA transcript. However, a number of considerations make it almost certain that the latter is correct. Firstly, the intensity of the larger band is always proportional to the intensity of the spliced mRNA protected fragment. Secondly, probing of the same RNA samples with the ET3 probe fails to show any evidence of full-length protection (see Fig. 5 below). Table I shows estimation of the efficiency of RNA recovery and quantitation of ET1 mRNA in each organ. It can be seen that ET1 mRNA was much more abundant in the lung than elsewhere. Variation in efficiency of RNA recovery from different organs was small and unlikely to contribute significantly to the large variations in ET1 mRNA abundance observed.

Fig. 4 shows the organ distribution of mRNA for ET2. The picture is clearly distinct from that of ET1. High levels of expression were obtained in both large and small intestine. Lower levels of expression (apparent on an autoradiograph exposed for $5 \mathrm{~d}$ ) were seen in heart, muscle, and stomach. Protected bands representing $\alpha$-globin mRNA and full-length protection of the ET2 probe by unspliced RNA are also seen. Table I shows quantitation of ET2 mRNA in those organs where expression was detected. No attempt was made to quantify ET2 mRNA in organs in which an autoradiograph exposed for $5 \mathrm{~d}$ failed to show a visible protected band.

Fig. 5 shows the organ distribution of mRNA for ET3. The pattern is different from that of either ET1 or ET2, the highest level of expression being seen in small intestine. Between the protected band running at $140 \mathrm{bp}$, compatible with the length of protected ET3 fragment predicted from the sequence data, and the $\alpha$-globin protected band, there are a number of other bands. The nature of these bands is uncertain. They were a constant feature of the ET3 protection assay and always present in proportion to the intensity of the 140-bp band. They may represent the formation of secondary structure in the RNA or reflect alternative splicing of the mRNA; indeed two consensus splice site sequences can be seen close together in the sequence data (Fig. 1). For the purposes of quantitation only the 140-bp band was excised from the gel. Table I shows that the level of expression of ET3 mRNA in different tissues was more evenly distributed than that of ET1, where the relative abundance of mRNA in lung was approximately five times greater than that in any other organ studied, or ET2, where levels of expression in the large and small intestines greatly exceeded those demonstrated elsewhere.

Effect of renal ischemia on ET gene expression. The total amount of RNA recovered from the postischemic and the contralateral control kidneys was not significantly different-total organ RNA: control $1.54 \pm 0.06 \mathrm{mg}$, postischemic $1.54 \pm 0.07$ $\mathrm{mg}$, postischemic minus control $0.00 \pm 0.06 \mathrm{mg}(n=30)$. Efficiency of $\alpha$-globin mRNA recovery was also similar in the two groups: control $54 \pm 4 \%$, postischemic $51 \pm 4 \%$, control minus postischemic $3 \pm 3 \%$. Figs. 6 and 7 illustrate the effects of a 45-min period of renal ischemia on the abundance of ET1 and ET3 mRNA over the following $7 \mathrm{~d}$. ET2 was not expressed in the control kidney and did not become evident at any time after ischemia. Table II shows quantitation, relative to the pooled kidney standard, of ET1 and ET3 mRNA in control and postischemic organs after both 25 - and 45 -min periods of 


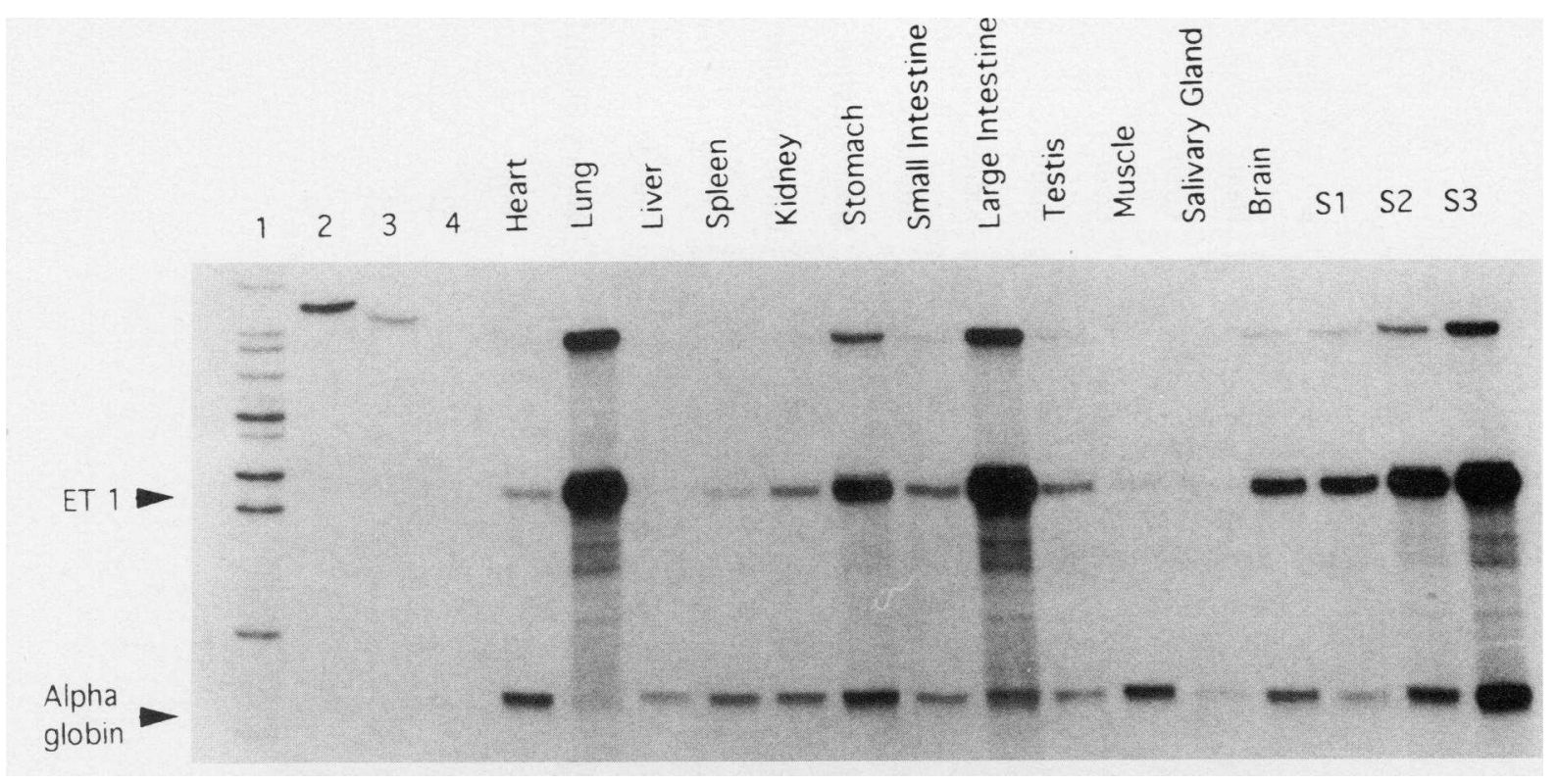

Figure 3. Autoradiograph, after $16 \mathrm{~h}$ of exposure, of an RNAase protection assay of ET1 mRNA in various rat organs. A total of $100 \mu \mathrm{g}$ of RNA was used in each hybridization reaction, except in the case of lung where $25 \mu \mathrm{g}$ was used. Lane 1: marker, Hpa II digest of pBR322. Lane 2: ET1 probe. Lane 3: $\alpha$ globin probe. Lane 4: hybridization without RNA. Lanes $S 1-S 3$ : standards containing 5, 10, and $20 \mu \mathrm{g}$ of pooled rat lung RNA and $0.5,1$, and $2 \mu \mathrm{g}$ of K562 (human erythroleukemia cell line) RNA. The ET 1 and $\alpha$-globin-protected fragments are indicated. Comparison of ET1 mRNA in each sample with that in the standards was used for quantitation (see Methods). Comparison of $\alpha$ globin mRNA with that in the standards was used to estimate the efficiency of RNA recovery in each sample (see Methods).

renal ischemia. The level of ET1 mRNA rose in the postischemic kidney. $2 \mathrm{~h}$ after relief of both 25 - and 45 -min periods of ischemia, the abundance had increased to over twice that in the pooled rat kidney standard, and $6 \mathrm{~h}$ after the longer insult the level had risen to $421 \pm 69 \%$ of standard. The effect was long-

Table I. Organ Distribution of mRNAs for ETs 1, 2, and 3

\begin{tabular}{lcccc}
\hline & & & & \\
& RNA & \multicolumn{2}{c}{$\begin{array}{c}\text { Percentage of pooled rat lung } \\
\text { recovery }\end{array}$} & \multicolumn{2}{c}{ ET1 } & ET3 & $\begin{array}{c}\text { of ET2 in } \\
\text { pooled rat } \\
\text { large intestine }\end{array}$ \\
\cline { 3 - 4 } & & \multicolumn{2}{c}{$\%$} & \\
Heart & $54 \pm 5$ & $2.8 \pm 1.2$ & $3.2 \pm 2.4$ & $4.3 \pm 0.8$ \\
Lung & $58 \pm 5$ & $102.8 \pm 29.4$ & $105.3 \pm 8.8$ & NQ \\
Liver & $52 \pm 4$ & $0.7 \pm 0.3$ & $2.9 \pm 1.3$ & NQ \\
Spleen & $51 \pm 5$ & $1.1 \pm 0.4$ & $4.9 \pm 1.9$ & NQ \\
Kidney & $52 \pm 5$ & $2.4 \pm 0.4$ & $61.6 \pm 6.3$ & NQ \\
Stomach & $51 \pm 5$ & $7.0 \pm 0.8$ & $46.8 \pm 10.4$ & $2.6 \pm 0.9$ \\
Small intestine & $60 \pm 4$ & $2.8 \pm 0.6$ & $159.8 \pm 27.9$ & $65.4 \pm 14.8$ \\
Large intestine & $63 \pm 5$ & $21.7 \pm 3.6$ & $63.8 \pm 6.6$ & $140.3 \pm 33.6$ \\
Testis & $51 \pm 5$ & $2.0 \pm 0.5$ & $7.7 \pm 1.6$ & NQ \\
Muscle & $46 \pm 5$ & $1.3 \pm 0.6$ & $12.6 \pm 2.3$ & $5.9 \pm 0.5$ \\
Salivary gland & $50 \pm 6$ & $0.9 \pm 0.4$ & $35.8 \pm 6.8$ & NQ \\
Brain & $57 \pm 5$ & $3.6 \pm 0.5$ & $53.5 \pm 3.5$ & NQ \\
& & & & \\
\hline
\end{tabular}

Efficiency of RNA recovery calculated from recovery of $\alpha$-globin mRNA as described in Methods. Abundance of ET mRNA in each organ expressed as a percentage of that found in pooled rat lung (ETs 1 and 3) or pooled rat large intestine (ET2) as described in Methods. Values expressed as means \pm SEM (efficiency of recovery, $n=12$ estimations in each group; ET mRNA abundance, $n=4$ in each group). $\mathrm{NQ}$, not quantifiable. lasting, with elevated values seen throughout the 7-d postischemic period. At no time point was ET1 mRNA in the contralateral control organ significantly different from that in the standard preparation. By contrast, the level of ET3 mRNA fell in the postischemic kidney. At $2 \mathrm{~h}$ the abundance had halved in both the 25- and 45-min groups, and at $6 \mathrm{~h}$ the level in the 45 -min ischemic group had dropped to $19 \pm 2 \%$ of standard. As with ET1 the effect of ischemia was persistent: reduced values of ET3 mRNA were seen in the postischemic organ throughout the period of observation. At no time after $25 \mathrm{~min}$ of ischemia was ET3 mRNA in the contralateral control organ significantly different from that in the standard preparation. However, at 2 and $6 \mathrm{~h}$ after $45 \mathrm{~min}$ of ischemia, it was significantly reduced, but this effect did not persist at $24 \mathrm{~h}$ and was not evident thereafter.

\section{Discussion}

This study demonstrates the expression of ETs 1, 2, and 3 in a variety of adult rat tissues. The organ distribution of mRNAs encoding each of the three isopeptides was distinct. ET1 mRNA was particularly abundant in the lung and moderately expressed in large intestine, and lower levels were detectable in all organs examined. ET2 was expressed at a high level in both large and small intestine; low levels were observed in stomach, muscle, and heart; but ET2 mRNA could not be detected in the other organs studied. Expression of ET3 could be demonstrated in all organs, the abundance of mRNA being more evenly distributed than that of ET1.

A number of techniques have previously been used to determine the production of ETs in various organs. These comprise estimates of tissue ET-like immunoreactivity (6-8), Northern blotting $(1,2,5,11,12,16)$, in situ hybridization ( 5 , $17)$, and polymerase chain reaction (18). 


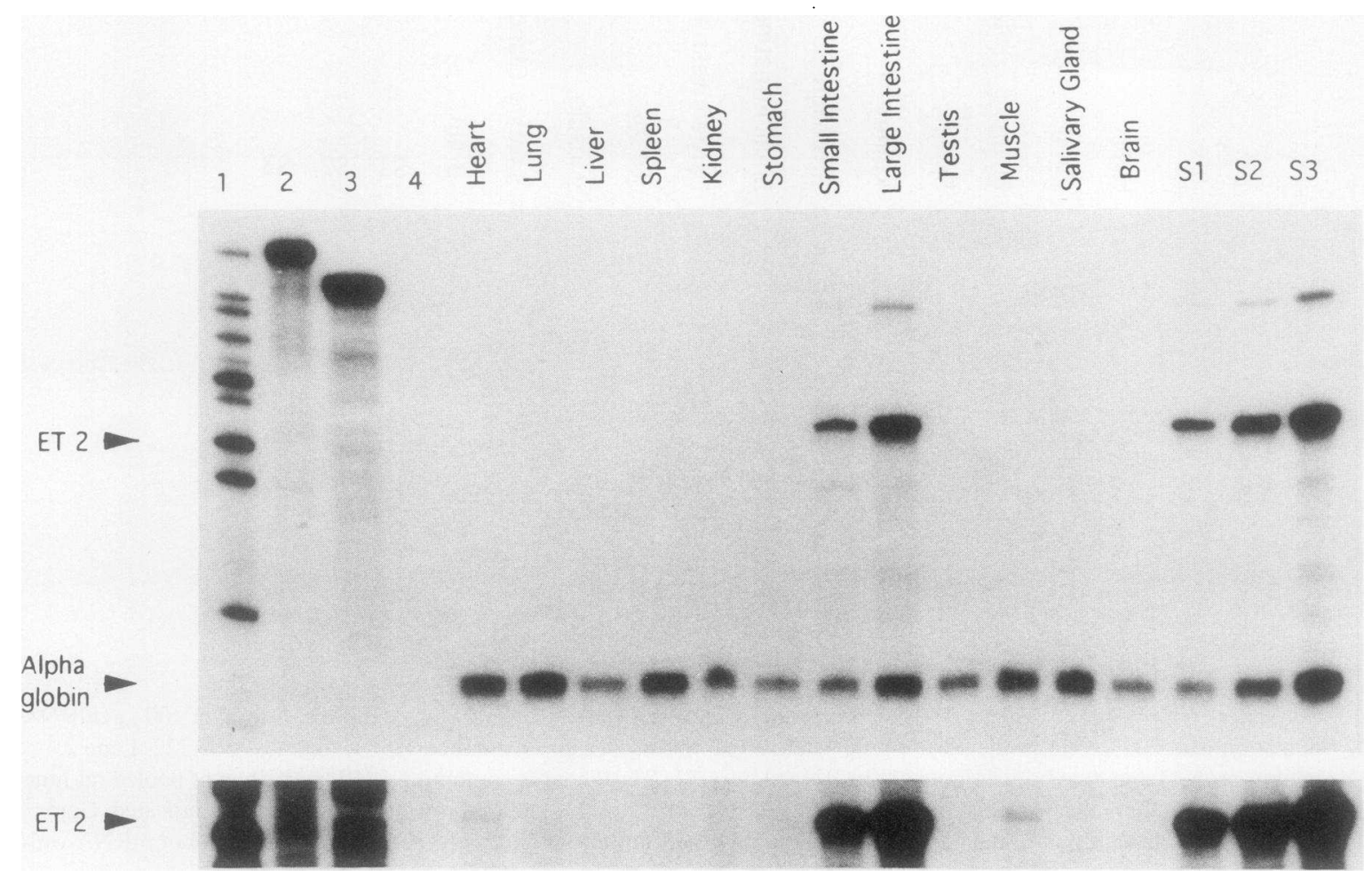

Figure 4. Autoradiograph, after $16 \mathrm{~h}$ (upper panel) and $5 \mathrm{~d}$ (lower panel) of exposure, of an RNAase protection assay of ET2 mRNA in various rat organs. A total of $100 \mu \mathrm{g}$ of RNA was used in each hybridization reaction. Lanes 1, 3, and 4: as Fig. 3. Lane 2: ET2 probe. Lanes S1-S3: standards containing 25,50 , and $100 \mu \mathrm{g}$ of pooled rat large intestine RNA and $0.5,1$, and $2 \mu \mathrm{g}$ of K562 RNA. The ET2 and $\alpha$-globin-protected fragments are indicated. For details of quantitation, see Fig. 3 and Methods.

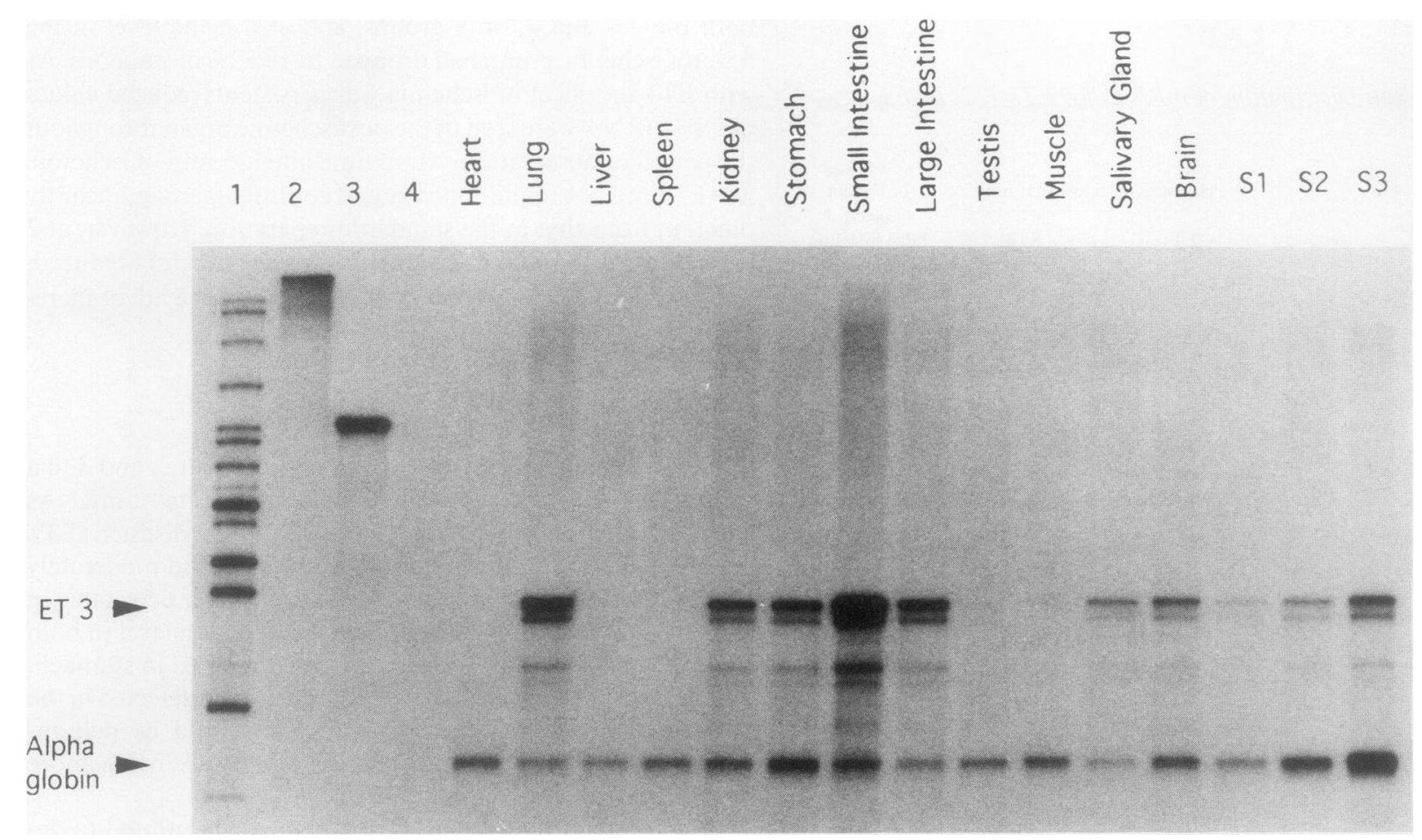

Figure 5. Autoradiograph, after $16 \mathrm{~h}$ of exposure, of an RNAase protection assay of ET3 mRNA in various rat organs. A total of $100 \mu \mathrm{g}$ of RNA was used in each hybridization reaction. Lanes 1, 3, and 4: as Fig. 3. Lane 2: ET3 probe. Lanes $S 1-S 3$ : standards containing 25 , 50 , and $100 \mu \mathrm{g}$ of pooled rat lung RNA and $0.5,1$, and $2 \mu \mathrm{g}$ of K562 RNA. The ET3 and $\alpha$-globin-protected fragments are indicated. For details of quantitation, see Fig. 3 and Methods. 


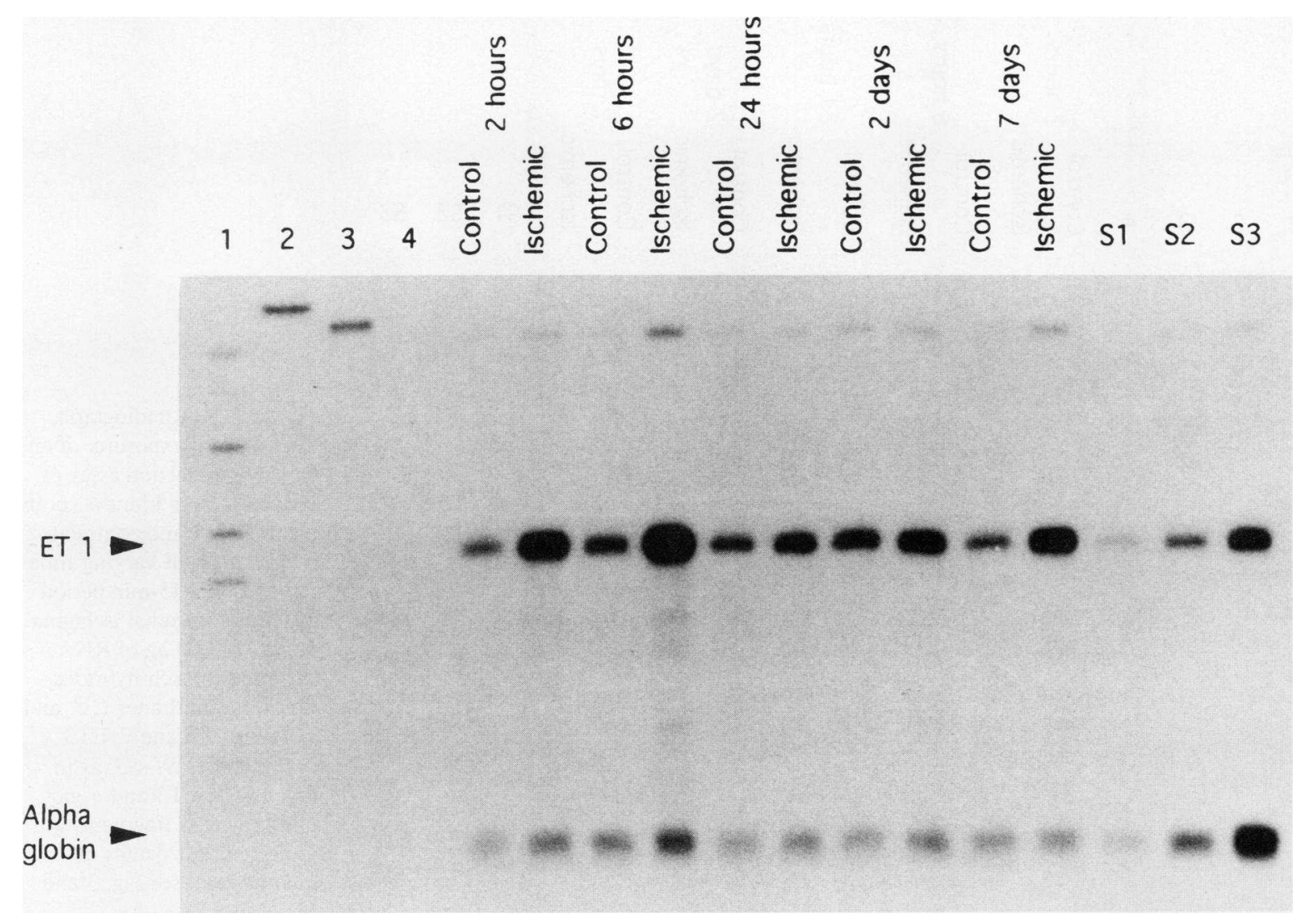

Figure 6. Autoradiograph, after $16 \mathrm{~h}$ of exposure, of an RNAase protection assay of ET1 mRNA in kidneys (both postischemic and contralateral control) at varying time points after a 45-min period of temporary renal ischemia. A total of $100 \mu \mathrm{g}$ of RNA was used in each hybridization reaction. Lanes 1-4: as Fig. 3. Lanes S1-S3: standards containing 50, 100, and $200 \mu \mathrm{g}$ of pooled rat kidney RNA and $0.5,1$, and $2 \mu \mathrm{g}$ of K562 RNA. The ET1 and $\alpha$-globin-protected fragments are indicated. For details of quantitation, see Fig. 3 and Methods.

The studies of ET-like immunoreactivity report the presence of immunoreactive material in all organs examined, with the exception of adrenal glands and colon (8), and with particularly high levels in renal medulla and lung (6). However, all of these studies suffer from the disadvantage that the antibodies used were incapable of distinguishing between the three ET isoforms.

The Northern blotting studies have produced a variety of conflicting results. Yanagisawa et al. (1) could not detect ET1 mRNA in brain, atrium, lung, or kidney. Inoue et al. (2) used probes for human ETs 1, 2, and 3 and examined a range of surgically obtained human tissues. No expression could be detected in any organ examined (frontal cortex, atrium, kidney, liver, spleen, stomach, placenta, testis, ovary, and uterus). By contrast, Bloch et al. $(11,12)$ detected low level expression of ET1 in fetal human lung, spleen, pancreas, atrium, and ventricle (but not in kidney or liver); ET2 in fetal human kidney; and ET3 in fetal human lung, spleen, pancreas, and kidney (but not in atrium, ventricles, or liver). MacCumber et al. (5) were able to detect ET1 and ET3 mRNA in some adult rat tissues: ET1 was expressed in lung and intestine (but not in eye, liver, kidney, right atrium, or cerebellum); ET3 was expressed in eye, kidney, lung, and cerebellum (but not in intestine, liver, or right atrium). Saida et al. (17) reported expression of ET2 in mouse intestine, but not in other murine tissues (brain, kidney, lung, liver, spleen, and stomach).

The reasons for the variable results obtained with Northern blotting have not been adequately explained. It has been suggested that differences may be attributable to developmental modulation of ET gene expression (12). Variation between species may also be important. A further possibility is that the differences may reflect the relative insensitivity of the Northern blotting technique, with levels of tissue expression of ET mRNAs being either below or close to the limit of detection. In comparison, the RNAase protection assay, which detected widespread expression of the ETs, is more robust to the minor degrees of RNA degradation that are inevitable in the preparation of RNA from whole organs and is a great deal more sensitive. For example, mRNA for erythropoietin is at the limit of detection by Northern blotting of samples from normal unstimulated kidney, yet it is readily apparent by RNAase protection (19). The suggestion that failure to detect tissue expression of ET mRNAs by Northern blotting might be due to the combination of relative insensitivity of technique and relatively low levels of transcript is supported by the findings of Nunez et al. (18). By using a polymerase chain reaction-based method requiring 60 cycles of amplification, they were able to detect the presence of ET1 sequence in cDNA from all pig tissues (aortic endothelial cell scrapings, each heart chamber, adrenal, and kidney) and all human tissues (each cardiac ventricle and lung) examined.

Three considerations mean that the ETs are plausible contenders for a role in the pathogenesis of acute renal failure: in particular regarding the persistent microcirculatory vasocon- 


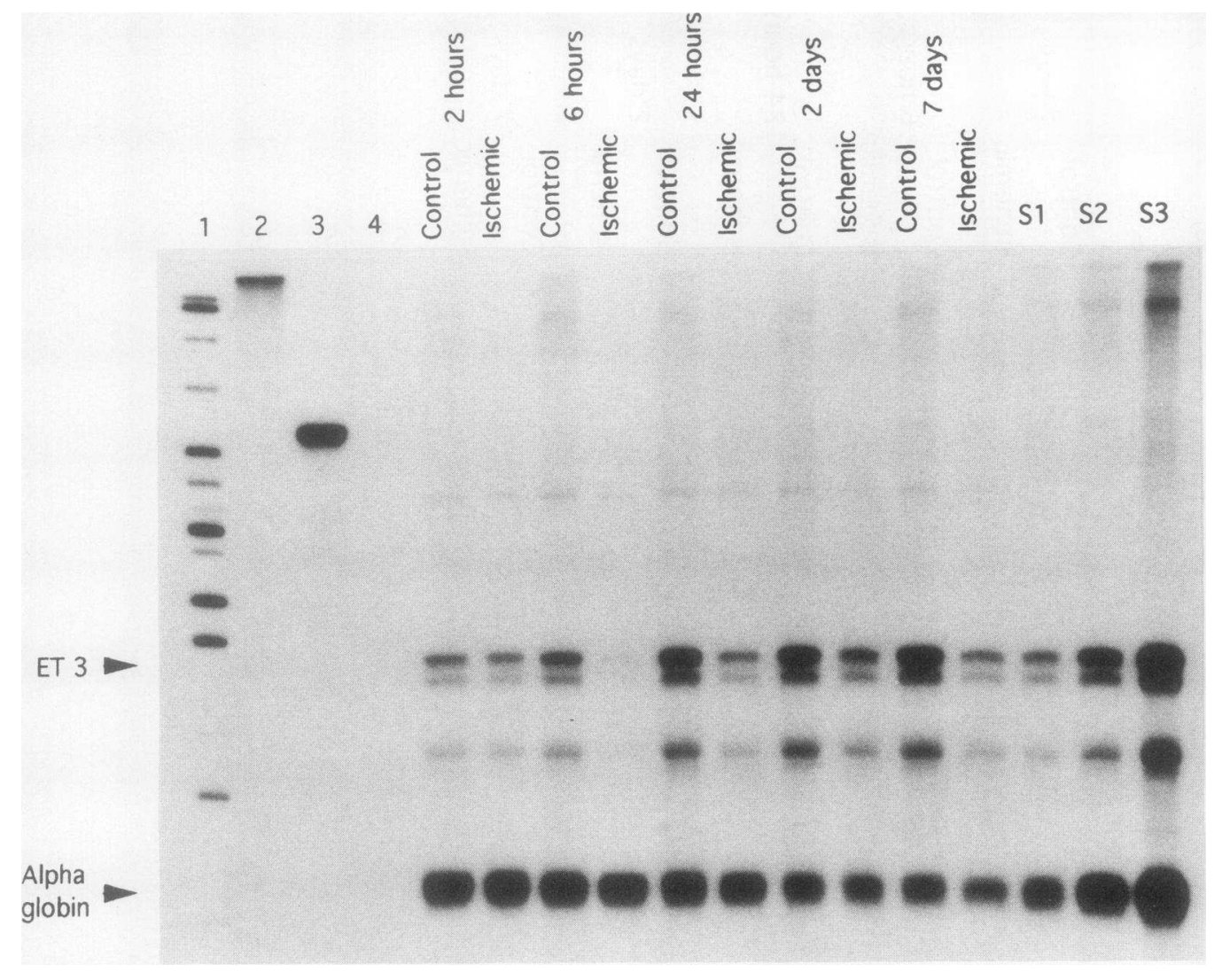

Figure 7. Autoradiograph, after $48 \mathrm{~h}$ of exposure, of an RNAase protection assay of ET3 mRNA in kidneys (both postischemic and contralateral control) at varying time points after a 45-min period of temporary renal ischemia. A total of $100 \mu \mathrm{g}$ of RNA was used in each hybridization reaction. Lanes 1,3 , and 4: as Fig. 3. Lane 2: ET3 probe. Lanes $S 1-S 3$ : as in Fig. 6. The ET3 and $\alpha$-globin-protected fragments are indicated. For details of quantitation, see Fig. 3 and Methods. striction that follows renal ischemia. The first is their ability to induce relatively long-lasting renal vasoconstriction and depression of filtration rate when infused intravenously (20), into the renal artery (21), or into the isolated kidney (22). The

Table II. Effect of Ischemia on Renal Expression of ETs 1 and 3

\begin{tabular}{ccccc}
\hline & \multicolumn{4}{c}{ Percentage of pooled rat kidney standard } \\
\cline { 2 - 5 } & $\begin{array}{c}\text { ET1 } \\
\text { control }\end{array}$ & $\begin{array}{c}\text { ET1 } \\
\text { ischemic }\end{array}$ & $\begin{array}{c}\text { ET3 } \\
\text { control }\end{array}$ & $\begin{array}{c}\text { ET3 } \\
\text { ischemic }\end{array}$ \\
\hline $\begin{array}{c}\text { Time after } 25 \text { min } \\
\text { of ischemia }\end{array}$ & & & & \\
2 h & $109 \pm 17$ & $220 \pm 16^{*}$ & $74 \pm 7$ & $53 \pm 6^{*}$ \\
6 h & $82 \pm 5$ & $199 \pm 62$ & $100 \pm 13$ & $52 \pm 6^{*}$ \\
24 h & $86 \pm 9$ & $125 \pm 18$ & $76 \pm 10$ & $53 \pm 6^{*}$ \\
2 d & $94 \pm 11$ & $180 \pm 48$ & $88 \pm 7$ & $36 \pm 5^{*}$ \\
7 d & $102 \pm 5$ & $135 \pm 22$ & $100 \pm 9$ & $84 \pm 10$ \\
Time after 45 min & & & & \\
of ischemia & & & & \\
2 h & $79 \pm 17$ & $263 \pm 39^{*}$ & $48 \pm 4^{*}$ & $43 \pm 4^{*}$ \\
6 h & $115 \pm 5$ & $421 \pm 69^{*}$ & $63 \pm 5^{*}$ & $19 \pm 2^{*}$ \\
24 h & $96 \pm 13$ & $129 \pm 28$ & $92 \pm 17$ & $40 \pm 6^{*}$ \\
2 d & $117 \pm 7$ & $171 \pm 17^{*}$ & $85 \pm 9$ & $56 \pm 9^{*}$ \\
7 d & $84 \pm 12$ & $212 \pm 35$ & $101 \pm 15$ & $47 \pm 9^{*}$ \\
\hline
\end{tabular}

Quantitation of ETs 1 and 3 in postischemic and contralateral control kidneys at various time points after the release of a unilateral renal artery clamp that had been applied for 25 or $\mathbf{4 5} \mathrm{min}$. Abundance of ET is expressed as a percentage of that found in a pooled rat kidney standard preparation as described in Methods. Values expressed as means $\pm \operatorname{SEM}$ ( $n=3$ each group). * Significantly different from standard (100\%) at $P<0.05$. second is evidence that infusion of anti-ET antibodies ameliorates the functional and histological changes resulting from a period of bilateral renal ischemia (23). The third is the dramatic observations of Kon et al. (24), who studied animals 48 $\mathrm{h}$ after a 25 -min period of renal ischemia and found that antiET antibody infused into one of the branches of the main renal artery attenuated the vasoconstriction characteristic of postischemic nephrons within the area infused. This led the authors to suggest that ET released locally from damaged endothelium might play an important role in the pathogenesis of the hypoperfusion and hypofiltration that is observed in this situation.

To pursue this possibility, and in particular to determine which isoform of ET might be responsible, we examined the changes in renal expression of the three ET genes at varying times after a 25- or 45-min period of unilateral renal ischemia. The observations in the postischemic kidney were clearcut: of the three mRNAs, that for ET1 increased substantially after ischemia, that for ET3 decreased, and that for ET2-not detectable in normal renal tissue by the RNAase protection technique used-remained undetectable. The findings support the possibility of a role for ET 1 in postischemic renal vasoconstriction and make it unlikely that ET2 is involved. The reduction in ET3 mRNA is hard to interpret; it being difficult to imagine how a fall in ET3 expression could lead to vasoconstriction. However, two possibilities, ( $a$ ) that ET3 has novel renal vasodilator actions or $(b)$ that ET3 acts as a partial agonist for renal ET1 receptors, could be argued to support a role for the reduction of ET3 mRNA in the generation of renal vasoconstriction, but there is no evidence to support either of these contentions. The observation of transient depression of ET3 mRNA in the control organ after $45 \mathrm{~min}$ of ischemia was unexpected. It would seem, however, to have been a genuine phenomenon- 
restricted among the ETs to ET3-in that parallel depression of ET1 mRNA was not observed.

The response to renal ischemia demonstrates, for the first time, a situation in which the expression of ET isoforms is clearly regulated in a differential manner: ET1 mRNA increased in the postischemic organ, while ET3 mRNA simultaneously decreased; ET3 mRNA fell transiently in the control kidney, whereas ET1 mRNA was unaffected. These findings indicate that ET isoforms are subject to control by distinct regulatory mechanisms they mean that the ETs cannot be considered in a manner that assumes that each isoform behaves in a similar way, and that an inducer or repressor of one will necessarily act likewise upon another. They also imply for immunoassays that cross-react between ETs that an observation of unchanged ET immunoreactivity does not exclude the possibility of important changes in ET gene expression, with induction of one isoform offset by repression of another.

A final point worthy of note is the longevity of the postischemic changes in expression of the ET genes. The mRNA for human ET1 is extremely labile, with an apparent intracellular half-life of $\sim 15 \mathrm{~min}(25)$. If the same is true of rat ET 1 , which would be consistent with the large proportion of primary transcripts observed, then this must imply that the increased levels of ET $1 \mathrm{mRNA}$ persistently observed after a short-lived period of renal ischemia are due to continuing induction of gene expression. The cause of such induction is not addressed by the present study, but postischemic entry of calcium may be a possibility, inasmuch as calcium entry has been reported to induce the expression of ET1 (1).

In summary, by using RNAase protection assays specific for each of the ET isoforms, we have demonstrated three distinct patterns of organ distribution of gene expression. We have also demonstrated a potential for differential regulation of the ET genes, with renal ET1 mRNA increasing and ET3 mRNA decreasing after a temporary period of renal ischemia.

\section{Acknowledgments}

The construct used to make the $\alpha$-globin riboprobe was kindly provided by Dr. R. W. Jones. Profs. D. J. Weatherall and J. G. G. Ledingham are thanked for helpful discussion and support. The technical assistance of $\mathrm{K}$. Yeates and J. Schultz is gratefully acknowledged, as are the secretarial skills of P. Hagar.

Dr. Ratcliffe is a Wellcome Senior Research Fellow. This work was supported by the National Kidney Research Fund (UK).

\section{References}

1. Yanagisawa, M., H. Kurihara, S. Kimura, Y. Tomobe, M. Kobayashi, Y. Mitsui, Y. Yazaki, K. Goto, and T. Masaki. 1988. A novel potent vasoconstrictor peptide by vascular endothelial cells. Nature (Lond.). 332:411-415.

2. Inoue, A., M. Yanagisawa, S. Kimura, Y. Kasuya, T. Mayauchi, K. Goto, and T. Masaki. 1989. The human endothelin family: three structurally and phar- macologically distinct isopeptides predicted by three separate genes. Proc. Natl. Acad. Sci. USA. 86:2863-2867.

3. Simonson, M. S., and M. J. Dunn. 1990. Cellular signaling by peptides of the endothelin gene family. FASEB (Fed. Am. Soc. Exp. Biol.) J. 4:2989-3000.

4. Hartter, E., and W. Woloszczuk. 1989. Radioimmunoassay of endothelin. Lancet. i:909.

5. MacCumber, M. W., C. A. Ross, B. M. Glaser, and S. H. Snyder. 1989. Endothelin: visualisation of mRNAs by in situ hybridisation provides evidence for local action. Proc. Natl. Acad. Sci. USA. 86:7285-7289.

6. Kitamura, K., T. Tanaka, J. Kato, T. Eto, and K. Tanaka. 1989. Regional distribution of immunoreactive endothelin in porcine tissue: abundance in inner medulla of kidney. Biochem. Biophys. Res. Commun. 161:348-352.

7. Pernow, J., A. Hemsen, and J. M. Lundburg. 1989. Tissue specific distribution, clearance and vascular effects of endothelin in the pig. Biochem. Biophys. Res. Commun. 161:647-653.

8. Yoshimi, H., Y. Hirata, Y. Fukuda, Y. Kawano, T. Emori, M. Kuramochi, T. Omae, and F. Marumo. 1989. Regional distribution of immunoreactive endothelin in rats. Peptides. 10:805-808.

9. Melton, D. A., P. A. Krieg, M. R. Rebagliati, T. Maniatis, K. Zinn, and M. R. Green. 1984. Efficient in vitro synthesis of biologically active RNA and RNA hybridization probes from plasmids containing a bacteriophage SP6 promoter. Nucleic Acids Res. 12:7035-7056.

10. Bloch, K. D., S. P. Friedrick, M.-E. Lee, R. L. Eddy, T. B. Shows, and T. Quertermous. 1989. Structural organisation and chromosomal assignment of the gene encoding endothelin. J. Biol. Chem. 264:10851-10857.

11. Bloch, K. D., C. C. Hong, R. L. Eddy, T. B. Shows, and T. Quertermous. 1991. cDNA cloning and chromosomal assignment of the endothelin 2 gene: vasoactive intestinal contractor peptide is rat endothelin 2. Genomics. 10:236242.

12. Bloch, K. D., R. L. Eddy, T. B. Shows, and T. Quartermous. 1989. cDNA cloning and chromosomal assignment of the gene encoding endothelin 3. J. Biol. Chem. 264:18156-18161.

13. Ohkubo, S., Y. Itoh, C. Kimura, H. Ouda, and M. Fujino. 1990. Nucleotide sequence of a rabbit genomic DNA encoding mature endothelin-3. Nucleic Acids Res. 18:374.

14. Potter, C. G., C. C. Tan, and P. J. Ratcliffe. 1991. Quantification of ${ }^{32} \mathrm{P}$-labeled samples in gel fragments using the flat bed liquid scintillation counter. Anal. Biochem. 197:121-124.

15. Padgett, R. A., P. J. Grabowski, M. M. Konarska, S. Seiler, and P. A. Sharp. 1986. Splicing of messenger RNA precursors. Annu. Rev. Biochem. 55:1119-1150.

16. Yanagisawa, M., A. Inoue, T. Ishikawa, Y. Kasuya, S. Kimura, S.-I. Kumagaye, K. Nakajima, T. X. Watanabe, S. Sakakibara, K. Goto, et al. 1988. Primary structure, synthesis, and biological activity of rat endothelin, an endothelium-derived vasoconstrictor peptide. Proc. Natl. Acad. Sci. USA. 85:6964-6967.

17. Saida, K., Y. Mitsui, and N. Ishida. 1989. A novel peptide, vasoactive intestinal contractor, of a new (endothelin) peptide family. J. Biol. Chem. 264:14613-14616.

18. Nunez, D. J. R., M. J. Brown, A. P. Davenport, C. B. Neylon, J. P. Schofield, and R. K. Wyse. 1990. Endothelin 1 mRNA is widely expressed in porcine and human tissues. J. Clin. Invest. 85:1537-1541.

19. Ratcliffe, P. J., R. W. Jones, R. E. Phillips, L. G. Nicholls, and J. I. Bell. 1990. Oxygen-dependent modulation of erythropoietin mRNA levels in isolated rat kidneys studied by RNase protection. J. Exp. Med. 172:657-660.

20. Miller, W. L., M. M. Redfield, and J. C. Burnett, Jr. 1989. Integrated cardiac, renal, and endocrine actions of endothelin. J. Clin. Invest. 83:317-320.

21. Katoh, T., H. Chang, S. Uchida, T. Okuda, and K. Kurokawa. 1990. Direct effects of endothelin in the rat kidney. Am. J. Physiol. 258:F397-F402.

22. Firth, J. D., P. J. Ratcliffe, A. E. G. Raine, and J. G. G. Ledingham. 1988. Endothelin: an important factor in acute renal failure? Lancet. ii:1179-1182.

23. Shibouta, Y., N. Suzuki, A. Shino, H. Matsumoto, Z.-I. Terashita, K. Kondo, and K. Nishikawa. 1990. Pathophysiological role of endothelin in acute renal failure. Life Sci. 46:1611-1618.

24. Kon, V., T. Yoshioka, A. Fogo, and I. Ichikawa. 1989. Glomerular actions of endothelin in vivo. J. Clin. Invest. 83:1762-1767.

25. Inoue, A., M. Yanagisawa, Y. Takuwa, Y. Mitsui, M. Kobayashi, and T. Masaki. 1989. The human preproendothelin gene. J. Biol. Chem. 264:1495414959. 